\title{
Buoyancy Regulation in Phaeocystis globosa Scherffel Colonies
}

\author{
Xiaodong Wang ${ }^{*}, 1$ and Kam W. Tang ${ }^{2}$ \\ ${ }^{I}$ Research Center for Harmful Algae and Aquatic environment, Jinan University, Guangzhou 510632, China \\ ${ }^{2}$ Virginia Institute of Marine Science, College of William and Mary, Gloucester Point, VA, 23062, USA
}

\begin{abstract}
Buoyancy of Phaeocystis globosa Scherffel (Prymnesiophyceae) colonies was investigated by measuring the vertical distribution of colonies in quiescent water where convection had been removed. Over $60 \%$ of the colonies exhibited negative buoyancy regardless of light condition or growth phase. Positively and neutrally buoyant colonies lost their buoyancy in the dark, but regained buoyancy upon return to the light. Colonies with closer cell packing; i.e., more cells per unit colonial surface area, had greater capability to remain buoyant. Our results suggest that colony buoyancy was not uniform within a $P$. globosa population, and that biological regulation of colony buoyancy required light energy.
\end{abstract}

Keywords: Buoyancy, colony, Phaeocystis globosa, light dependent, growth phase.

\section{INTRODUCTION}

Phaeocystis (Prymneisophyceae), a phytoplankton genus that forms massive blooms world-wide [1], has a complex polymorphic life cycle with phase alternation between freeliving cells of 3-9 $\mu \mathrm{m}$ in diameter and gelatinous colonies that reach up to $3 \mathrm{~cm}$ in diameter [2,3]. Colonies of Phaeocystis are surrounded by thin mucous skins, with the colonial cells distributed along the periphery and weakly interconnected by diluted gel $[4,5]$. The colonial form is often the dominant morphotype in a Phaeocystis bloom [6, 7]. For a phytoplankton bloom to form, the growth and accumulation rates must exceed the loss rate due to viral lysis, grazing, advection and sinking [8]. It has been postulated that the mucous skin of Phaeocystis colonies protects the colonial cells from viral infection [9]. Studies thus far have shown that viral infection rate drastically decreases with colony formation and growth [10]. During active growth the average colony size of a Phaeocystis population increases [11, 12]. Ambient zooplankton grazing activity further stimulates the growth of the colonies in size, which may exacerbate the size-mismatch problem for the grazers $[13,14,15]$. The tough mucous skin of a healthy colony may also impede zooplankton grazing [16]. Reported grazing mortality rates of actively growing Phaeocystis colonies are generally lower than those of free-living cells [17]. Therefore, neither viral lysis nor grazing appears to be a major loss factor for actively growing Phaeocystis colonies. By comparison, the role of sinking in regulating the bloom dynamics of Phaeocystis has received little attention.

Because the colonial form lacks motility, Phaeocystis colonies must overcome sinking in order to maintain their position in the euphotic zone where sufficient light is available for photosynthesis. Positive buoyancies have been observed for Phaeocystis colonies (Table 1). Reported maximum ascendance rate of the colonies ranges from 0.1 to as

*Address correspondence to this author at the Research Center for Harmful Algae and Aquatic environment, Jinan University, Guangzhou 510632, China; Tel: +86 1526426 7458; E-mail: pouchetii@gmail.com high as $24 \mathrm{~m} \mathrm{~d}^{-1}[18,21]$. However, negative colonial buoyancy has also been reported, even in the same study where positive buoyancy was noted [21]. Reported sinking rate of Phaeocystis colonies ranges from 1 to $7 \mathrm{~m} \mathrm{~d}^{-1}[19,21,22]$. The SetCol method [23], widely used in measuring the sinking rate of Phaeocystis, gives only the mean population sinking rate, and the movements of individual colonies within the experimental container remain unknown. Skreslet [18] instead directly observed the rising velocity of $P$. pouchetii (Hariot) Lagerheim colonies within a container after the container was overturned, which obviously would have generated convection and increased the movement of the colonies. Therefore, the rising velocity of $P$. pouchetii colonies reported by Skreslet is likely an overestimation.

Although growth phase and energy are important factors that affect phytoplankton buoyancy [24, 25], their roles remain unknown in the case of Phaeocystis colony. Colony increases its size during growth, which is accompanied by increasing colonial cell number. Due to the higher density of colonial cells than seawater [21], change in colonial cell number will directly influence the density, hence buoyancy, of the colonies. On the other hand, entrapment of gas or increasing cellular lipid during active growth may help reduce colony sinking rate [21]. In addition, there is an energy requirement for phytoplankton to maintain their position in the water column [23]. The highest and lowest sinking rates are usually found when phytoplankton cells are grown at limiting and saturating irradiance, respectively [25]. Colonies of $P$. antarctica Karsten exhibit buoyancy regulation when placed in an illuminated incubator [26], but Skreslet suggested that the difference in colony buoyancy between light and dark conditions is not significant [18].

Given the ecological significance of Phaeocystis colonies and conflicting literature results concerning their sinking rates, it is necessary to more systematically study buoyancy of Phaeocystis colonies. In this study, we directly observed the distribution of $P$. globosa Scherffel colonies within experimental containers and investigated the ability of colonies to regulate buoyancy after the effect of convection 
Table 1. Reported Sinking Rates $\left(\mathrm{m} \mathrm{d}^{-1}\right)$ of Phaeocystis Colonies. *Negative Numbers Represent Positive Buoyancy, A Means Average Value, M Means Maximum Value

\begin{tabular}{|c|c|c|c|c|c|}
\hline Species & Location & Sinking rates $\left(\mathbf{m ~ d}^{\mathbf{1}}\right)$ & Method & Container volume (V) and height (H) & References \\
\hline \hline P. pouchetii & Lab & $-24(\mathrm{M}) *$ & Direct observation & $\mathrm{V}=1 \mathrm{ml} ; \mathrm{H}=58 \mathrm{~mm}$ \\
\hline Phaeocystis sp. & Lab & $5-7$ & SetCol & Unknown & Unknown \\
\hline Phaeocystis sp. & Marsdiep area & $3(\mathrm{M})$ & Unknown & Unknown \\
\hline P. globosa & Lab & $2(\mathrm{M})$ & Unknown & V $=229 \mathrm{ml} ; \mathrm{H}=20 \mathrm{~cm}$ & {$[20]$} \\
\hline P. globosa & South Bay & $1.29(\mathrm{~A})$ & SetCol & V $=229 \mathrm{ml} ; \mathrm{H}=20 \mathrm{~cm}$ \\
\hline P. globosa & South Bay & $-0.1(\mathrm{~A}) *$ & SetCol & Unknown \\
\hline P. antarctica & Ross sea & $3(\mathrm{M})$ & SetCol & {$[21]$} \\
\hline
\end{tabular}

in the containers had been removed or otherwise corrected for. We also studied the relationship between buoyancy and colony morphology, as well as the effect of light and growth phases on colony buoyancy. This study will help understand the role of buoyancy in controlling the population dynamics of Phaeocystis colonies.

\section{MATERIALS AND METHODOLOGY}

\section{Collection of $P$. globosa Single Cells}

Phaeocystis globosa (CCMP1528) was maintained in active growth in $\mathrm{f} / 2$ medium [27] with a salinity of $30 \mathrm{psu}$ at $19.6{ }^{\circ} \mathrm{C}$ under an irradiance of $50 \mu \mathrm{mol}$ photons $\mathrm{m}^{-2} \mathrm{~s}^{-1}$ in a $12 \mathrm{~h}: 12 \mathrm{~h}$ light/dark cycle. Solitary $P$. globosa cells were collected by passing the stock culture through a $10 \mu \mathrm{m}$ sieve under gravity and used to initiate colony growth [14].

\section{Vertical Distribution of Colonies}

Rectangular shaped experimental flasks (Corning, USA) were placed in a $15-\mathrm{L}$ aquarium filled with water to minimize temperature fluctuation. The aquarium was maintained at a temperature of $19.6{ }^{\circ} \mathrm{C}$. The volume and height of medium in each experimental flask was $250 \mathrm{ml}$ and $12 \mathrm{~cm}$, respectively, and the level of medium in the flasks was below the water level in the aquarium. This volume was comparable to the SetCol used by Peperzak et al. [21], but the height was less. The average colony size in our experiments was approximately $300 \mu \mathrm{m}$; hence, the height of the medium was equivalent to about 400 colony diameters. All the flasks were capped to prevent evaporation. Illumination (50 $\mu$ mol photons $\mathrm{m}^{-2} \mathrm{~s}^{-1}$ ) was provided from the side by cool-white fluorescent lamps with a $12 \mathrm{~h}: 12 \mathrm{~h}$ light/dark cycle. This light level is close to the reported threshold for colony formation for this phytoplankton species, and lower than the typical spring-summer light intensity within the euphotic zone in tropical to temperate regions, the geographical range for P. globosa blooms $[1,28]$.

Before the vertical distribution experiments, 30 flasks were inoculated with solitary $P$. globosa cells at an initial concentration of $1 \times 10^{3}$ cells $\mathrm{ml}^{-1}$, capped and left undisturbed in the aquarium. Every two day, 2 of the flasks were removed from the aquarium, mixed gently, and $10 \mathrm{ml}$ aliquots were drawn from the flasks for cell counts [13].
These procedures were repeated for up to 30 days, and the growth phases of the phytoplankton were determined based on the change in cell abundance (Fig. 1).

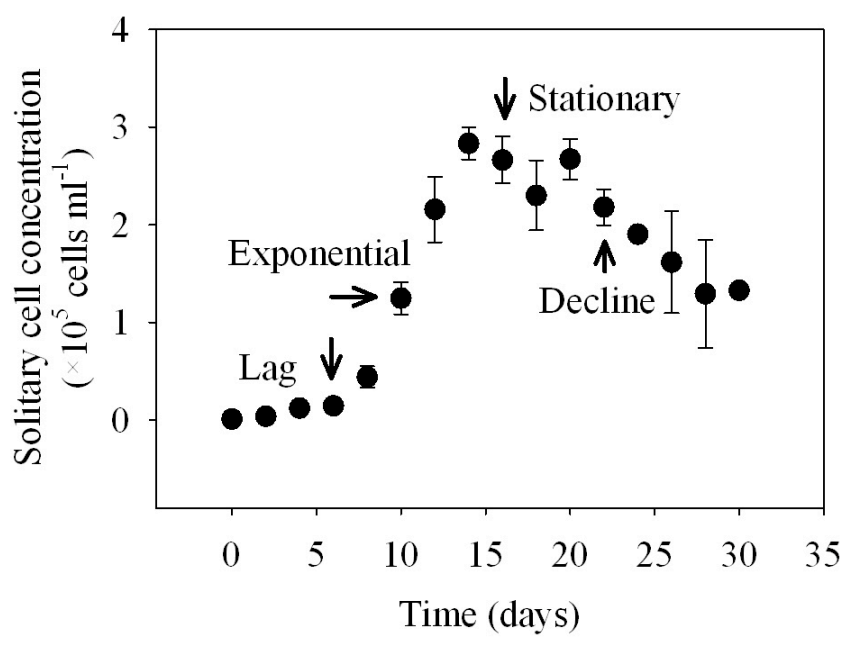

Fig. (1). Concentration of Phaeocystis globosa cells in experimental flasks through time (mean + s.d.; $n=2$ ). Arrows indicate the growth phases used for measuring vertical distribution of colonies.

After establishing this growth curve, another 24 flasks were set up and left undisturbed under identical conditions, and colony buoyancy was measured when the phytoplankton had reached lag phase (LP, $6^{\text {th }}$ day), exponential phase (EP, $10^{\text {th }}$ day) and stationary phase (SP, $16^{\text {th }}$ day) based on the previously established growth curve. Experiments for decline phase (DP, 22 $2^{\text {nd }}$ days) were also attempted but unsuccessful because of the lack of intact colonies. At each growth phase, 6 of the flasks were sacrificed for measuring vertical distribution of colonies as follows: 3 of the flasks were sampled $30 \mathrm{~min}$ before the end of the light period, and 3 were sampled $30 \mathrm{~min}$ before the end of the dark period. Samples were drawn from $0-1.5 \mathrm{~cm}$ (top), $1.5-11 \mathrm{~cm}$ (middle) and 11-12 cm (bottom) depth with silicone tubing connected to a peristaltic pump (Fisher Scientific, USA), and immediately preserved with $4 \%$ acid Lugol's solution. For the purpose of this study, colonies in the top layer were considered positively or neutrally buoyant, colonies in the middle layer were considered neutrally buoyant, and 
colonies in the bottom layer were negatively buoyant. Colonies within each extracted layer were measured for abundance, size and cells per colony according to the method of Jakobsen and Tang [13].

\section{Test for Convection}

An experiment was conducted to test how long it would take for convection to dissipate in our experimental flasks: Three flasks filled with seawater were left undisturbed for 5 days in the aquarium, and three additional flasks were first shaken and then left undisturbed for only 1 day. Afterward, a drop of red dye $\left(\right.$ density $\left.=1010.7 \mathrm{~kg} \mathrm{~m}^{-3}\right)$ was added gently to each of the flasks at the surface and the travelling patterns of the dye were observed. In the absence of convection the dye would be expected to travel downward along a straight line because of its higher density than the seawater (density = $1009.7 \mathrm{~kg} \mathrm{~m}^{-3}$ ), whereas if convection was present the dye would travel in random directions.

An additional experiment was conducted to test how convection, if present, may have affected the vertical distribution of colonies. Six flasks inoculated with $P$. globosa were left undisturbed in the aquarium until the phytoplankton reached lag phase, at which time $0.7 \mathrm{ml} \mathrm{37 \%}$ formaldehyde solution was slowly added to the water surface in three of the flasks for a final concentration of $0.1 \%$. This concentration of formaldehyde was sufficient to kill without causing disintegration of the colonies [21] or significantly affecting the density of seawater or colony. The other three flasks were shaken gently before addition of formaldehyde such that the dead colonies were distributed evenly in the flasks initially. All the flasks were then left undisturbed in the aquarium for $24 \mathrm{~h}$ before the distributions of dead colonies were measured. In the absence of convection all dead colonies would be expected to settle to the bottom.

\section{Transfer Experiment}

To further confirm that the observed vertical distribution reflects the innate ability of the colonies to regulate their buoyancy, an experiment was conducted where ten colonies each from the top $(0-1.5 \mathrm{~cm})$ and bottom $(11-12 \mathrm{~cm})$ layers of a flask were transferred with a wide-mouth pipette to just underneath the surface of a new flask that had been left undisturbed for 5 days, and the travelling patterns of the transferred colonies were observed. Colonies from top layer would be expected to remain in the top layer after transfer, whereas colonies from the bottom layer would be expected to sink to the bottom after transfer.

\section{Extended Dark Treatment}

Experiment was conducted to test the effect of extended darkness on colony buoyancy. Six flasks inoculated with $P$. globosa were allowed to grow undisturbed to lag phase, after which the light was turned off for $72 \mathrm{~h}$. At the end of the extended dark period, the vertical distribution of colonies was measured in three of the flasks. The other three flasks were re-exposed to light for $12 \mathrm{~h}$, and the final vertical distribution of colonies was measured.

\section{RESULTS}

\section{Vertical Distribution of Colonies}

Among the light period samples, the average colony concentration was 52, 361 and 401 colonies $\mathrm{ml}^{-1}$ at LP, EP and SP, respectively. Colonies suspended in top and middle layers were observed in all flasks, although colonies in bottom layer accounted for $>60 \%$ of the total (Table 2 ). The percentage of colonies in top and middle layers combined was $38.6 \%$ at LP, $35.8 \%$ at EP, and $30.7 \%$ at SP. Among the dark period samples, mean colony concentration was 66,329 and 341 colonies $\mathrm{ml}^{-1}$ at LP, EP and SP, respectively. Colonies in top and middle layers together accounted for $25.0 \%$ at LP, $21.9 \%$ at EP, and $20.5 \%$ at SP (Table 2). There was a significant difference in average percentage of colonies in top and middle layers between dark and light periods $(\mathrm{P}<0.05$, normalized by Arcsin square root test followed by t-test) such that more colonies were able to remain in suspension in the light than in the dark. The vertical distributions of colonies between LP, EP and SP were not significantly different ( $\mathrm{P}>0.05$, One-way ANOVA). Hence, contrary to expectation, growth phase had insignificant effect on colony buoyancy.

\section{Colony Morphologies}

There was no significant difference in either colony diameter or cells per colony between dark and light periods ( $\mathrm{P}>0.05$, Mann-Whitney test) (Fig. 2). However, in all of the growth phases tested, colony morphology differed between the different layers such that colonies in bottom layer were on average smaller in diameter than those in top and middle layers $(\mathrm{P}<0.05$, Kruskal-Wallis test followed by Dunn's pairwise comparison) (Fig. 2). Colonies in bottom layer also had on average fewer cells per colony than those in top and middle layers in both light and dark periods $(\mathrm{P}<0.05$, Kruskal-Wallis test followed by Dunn's pair-wise comparison) (Fig. 2).

Table 2. Mean Concentrations and Percent Distribution of Phaeocystis globosa Colonies in Top, Middle and Bottom Water Column Layers During Light and Dark Periods for Different Growth Phases

\begin{tabular}{|c|c|c|c|c|c|c|c|c|}
\hline \multirow{2}{*}{$\begin{array}{l}\text { Growth } \\
\text { phase }\end{array}$} & \multicolumn{4}{|c|}{ Light } & \multicolumn{4}{|c|}{ Dark } \\
\hline & $\begin{array}{l}\text { Colony concentrations } \\
\left(\text { colonies } \mathrm{ml}^{-1}\right)\end{array}$ & Bottom (\%) & Middle (\%) & Top (\%) & $\begin{array}{l}\text { Colony concentrations } \\
\left(\text { colonies } \mathrm{ml}^{-1}\right)\end{array}$ & Bottom (\%) & Middle (\%) & Top (\%) \\
\hline Exponential & 361.1 & 64.2 & 35.0 & 0.8 & 329.1 & 78.1 & 21.6 & 0.3 \\
\hline Stationary & 400.9 & 69.3 & 30.1 & 0.6 & 341.0 & 79.5 & 20.0 & 0.5 \\
\hline
\end{tabular}




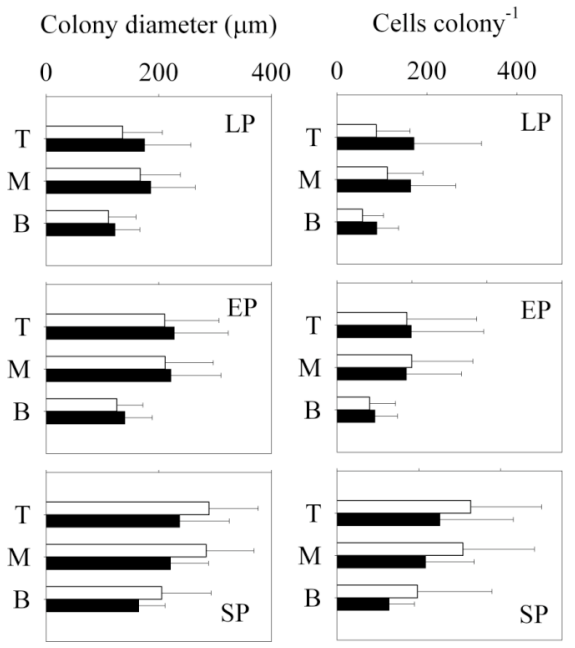

Fig. (2). Colony size and colonial cell abundance (mean + s.d.) of Phaeocystis globosa in different water column layers during light (white) and dark (black) periods for different growth phases. LP = lag phase; $\mathrm{EP}=$ exponential phase; $\mathrm{SP}=$ stationary phase. $\mathrm{T}=$ top layer; $\mathrm{M}=$ middle layer; $\mathrm{B}=$ bottom layer.

Because cell packing, expressed as cells per unit colony surface area, changes with colony size $[13,29]$, we examined

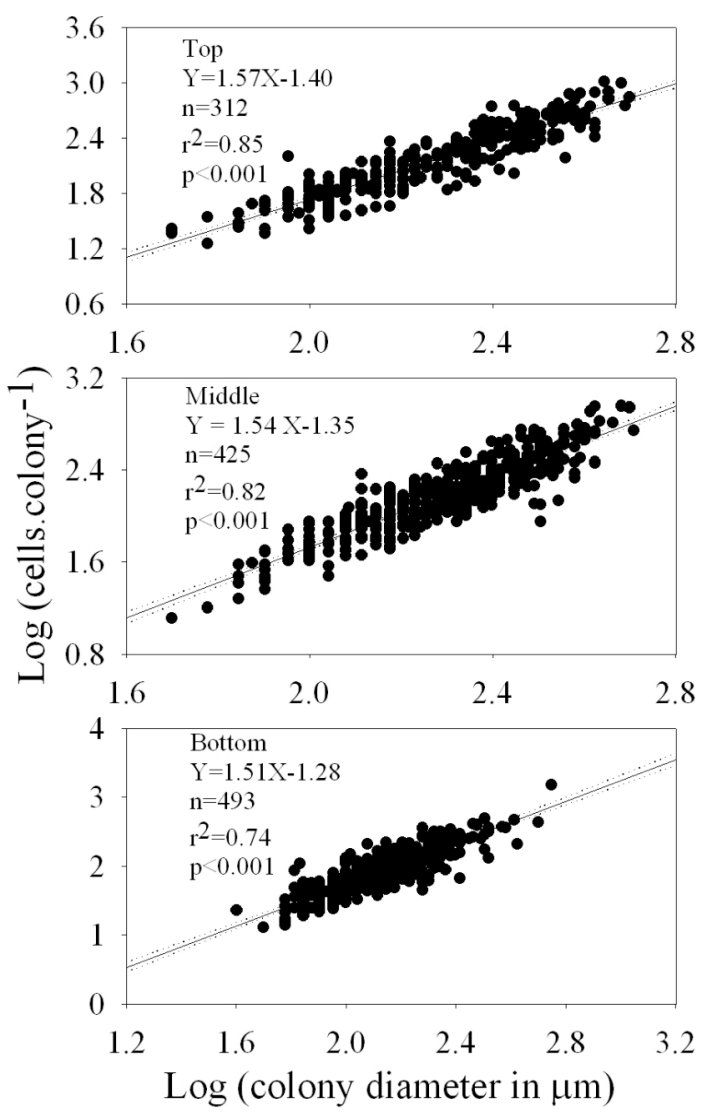

Fig. (3). Log-log relationship between cell numbers and colony size of Phaeocystis globosa in different water column layers. Data were pooled from light and dark periods and different growth phases. Linear regression and the $95 \%$ confidence intervals are shown. Equations for the regression lines, sample sizes (n), explained variances $\left(\mathrm{r}^{2}\right)$ and significance level $(p)$ are also presented. the relationship between colony buoyancy and cell packing as follows: Data were pooled from light and dark periods for the different growth phases, and cells per colony were plotted against colony diameter on a log-log plot for the different layers (Fig. 3). The slope of linear regression was $1.57,1.54$ and 1.51 for top, middle and bottom layer, respectively (Fig. 3). A slope value of less than 2 is consistent with previous studies $[13,29]$, and indicates that the packing of cells per unit colony surface area decreased as the colonies increased in size.

\section{Test for Convection}

When added to the flasks that had settled for only 1 day, the dye moved in random directions instantly. In contrast, when added to flasks that had settled for 5 days, the red dye moved vertically downwards, and the path remained visible and straight for at least $30 \mathrm{~min}$, indicating the absence of convection. In the experiment where the colonies were killed by formaldehyde, $>99 \%$ of the colonies settled to the bottom. However, when the flasks were shaken and then let settled for only 24 hours, a high percentage (mean $39.5 \pm$ s.d. $2.2 \%$ ) of the dead colonies remained in suspension.

\section{Transfer Experiment}

Of the 10 colonies that were transferred from the top layer to a new flask, only two lost their buoyancy and sank to the bottom. The other eight colonies stayed in the top layer for 3-8 days. As expected, colonies originated from the bottom layer began to move downward immediately after transfer and remained at the bottom.

\section{Extended Dark Treatment}

After being kept in darkness for $72 \mathrm{~h}$, colony abundance in top and middle layers together was significantly reduced to only $0.5 \pm 0.2 \%$ (mean \pm s.d.). After 12 hour re-exposure to light, however, the percentage of colonies in the top and middle layers combined was $25.7 \pm 4.1 \%$, comparable to the vertical distribution observed in earlier experiments ( $P$ $>0.05$, normalized by Arcsin square root test followed by $t-$ test).

\section{DISCUSSION}

\section{Avoiding Convection in Buoyancy Measurements}

The SetCol method has been commonly used to study buoyancy of Phaeocystis colonies. However, many researchers did not quantify or remove the effect of convection prior to measurements. Beinfang [23] also cautioned the existence of turbulence within SetCol although it would dissipate over time. The unknown intensity of turbulence within SetCol, particularly for measurements where the water was not allowed to settle for sufficient time, may have contributed to the variable and sometimes very high colony ascending rate or sinking rate. To remedy this problem, Walsby and Holland [30] installed a salinity gradient in their experimental container to suppress convection when measuring phytoplankton sinking rates. Our tests with red dye and formaldehyde-killed colonies showed that convection was still present after the flasks had been left undisturbed for 24 hours, and strong enough to keep a high percentage of 
negatively buoyant (dead) colonies in suspension. The red dye experiment also showed that convection could be removed by allowing the medium to settle for 5 days. Because we left the experimental flasks undisturbed for 5 days or more prior to buoyancy measurements, our results were not affected by convection.

Another potential problem with the SetCol method is wall effect by which the movement of colonies is hindered by the presence of walls of the container [21]. However, our transfer experiment showed not only that colonies originated from top layer remained in top layer after transfer to a new flask, but also that colonies originated from bottom layer sank immediately and freely after transfer. Hence, wall effect appeared to be negligible in our experimental flasks, and the observed vertical distribution of colonies was a result of innate ability of the colonies to regulate their buoyancy.

\section{Light Requirement for Buoyancy Control}

Our results confirmed that buoyancy was not uniform within a $P$. globosa colony population, and that a fraction of the population was capable of maintaining neutral to positive buoyancy. $P$. globosa colonies also displayed different buoyancy between light and dark periods. In extended darkness almost all of the colonies settled to the bottom, but some of them regained buoyancy when returned to the light. This strongly suggested that buoyancy control was light dependent. These results are in agreement with other studies, which found that young and healthy Phaeocystis colonies demonstrated buoyancy regulation in illuminated incubator or in seawater where irradiance was high [21,26]. The relationship between light energy and sinking has also been documented for diatoms. For example, the diatom Ditylum brightwellii (West) Grunow requires light to remain suspended near sea surface, and the lowest sinking rate occurs when the cells are grown under saturating irradiance [25]. Diurnal variability in diatom sinking rates has also been reported such that positive buoyancy is observed during the light period, followed by maximal sinking rate in the dark period $[31,32]$.

Although it is clear that light energy is required for Phaeocystis colonies to regulate their buoyancy, the mechanism by which they do so is unclear. Regulation of carbohydrate ballasting material is considered one of the major mechanisms for the change in phytoplankton buoyancy [33-35]. Previous experiments also demonstrated that light governs the amount of intracellular storage glucan, and glucan concentration of $P$. pouchetii shows strong diel variations and increases with light levels [36]. Diel changes in the amount of carbohydrate in colonial matrix may alter the ballast of the colonies. Some diatoms reduce cell density by increasing cellular lipid content or excluding ions [37]. Lipids in algae tend to increase during the light period and decrease during the dark period, which may help provide positive buoyancy during daytime [38].

Phaeocystis colonies can store energy in the colonial matrix when light is sufficient $[6,39,40]$, and the colonial cells may use this energy at night to sustain growth [41]. If so, colonies also may use this energy to maintain buoyancy, as indicated by the ability of some colonies to remain suspended during the 12-h dark period in our experiments. Waite et al. [25] also suggested that the availability of stored energy would allow a diatom cell to avoid short-term energy limitation and sustain low sinking rate. However, in continuous darkness the colonies would eventually deplete stored energy and sink, as what we observed in our extended dark treatment. It is also important to note that the colonies did not permanently lose their ability to regulate buoyancy in long darkness because many of them regained buoyancy upon re-exposure to light.

\section{Effects of Colony Structures and Growth Phases on Buoyancy}

In a $P$. globosa colony, individual cells are distributed within a mucous envelope while the colony interior remains fluid-filled [4]. Hence, the density of a colony is determined by the combined density of colonial cells, mucous envelope and interior fluid. Peperzak et al. estimated the density of colonial cells to be $1090 \mathrm{~kg} \mathrm{~m}^{-3}$ under nutrient replete condition [21], which is denser than the seawater in our experiments $\left(\sim 1009.7 \mathrm{~kg} \mathrm{~m}^{-3}\right)$. The mucous envelope is believed to be made of primarily carbohydrates, but its composition remains largely unknown [4]; hence, estimating its density is difficult. Nonetheless, colonial mucous with no or few cells is commonly found in sediment traps [42]. In our experiments, many colonies remained buoyant for many days until they ruptured, after which materials derived from the mucous envelope fell to the bottom. These observations suggest that the mucous materials likely have a higher density than seawater. Therefore, for a colony to achieve neutral or positive buoyancy, it must reduce the density of its interior fluid. Because colonial cells have higher density than seawater, for any given colony size, higher cell abundance would mean higher sinking rate. On the other hand, if buoyancy regulation requires active biological processes, higher cell abundance would also mean higher ability to maintain buoyancy. In our experiment, cell packing (i.e., number of cells per unit colony surface area) was highest in the top layer, followed by the middle layer, and lowest in the bottom layer (slopes of regression lines in Fig. 3). This observation suggests that biological manipulation by the colonial cells more than compensated for the increased total cell mass, and allowed the colony to achieve neutral to positive buoyancy. Direct measurement of interior fluid density has not been attempted, although some investigators have shown that oxygen concentration and $\mathrm{pH}$ inside a colony change during photosynthesis [43]. It is possible that a colony can physiologically manipulate the interior fluid chemistry and hence the overall density of the colony when light energy is available.

The lack of effect of growth phases on colony buoyancy was different than for other phytoplankton species. Generally the sinking rate of diatoms reaches minimum at log growth phase, and increases afterward [23, 44]. In our experiments, the vertical distribution of colonies remained the same from lag phase to stationary phase. Unfortunately we did not have data for decline phase, although rapid sinking of Phaeocystis materials at the end of a bloom is commonly observed in the field [45], again suggesting that senescent or dying colonies lack the ability to regulate buoyancy. 


\section{Buoyancy and Population Dynamics of Phaeocystis Colonies}

Colony formation helps Phaeocystis defend against grazing and viral lysis [10], which may contribute to the success of this genus. Unlike grazing and viral lysis, the importance of sinking loss is rather uncertain. Some investigators have suggested that sinking is relatively unimportant as a loss factor during Phaeocysits blooms [19, 46]. In contrast, our study showed that while some colonies remained in suspension, there was always a high percentage $(>60 \%)$ of the colonies that were negatively buoyant regardless of the light condition and growth phase. This indicates a strong tendency for a large fraction of the population to sink, which could limit the rate at which Phaeocystis colonies accumulate at sea surface during a bloom. However, it is also important to note the difference between our experimental set up and the natural environment. In our experiments the vertical distribution of colonies was measured in quiescent water, whereas turbulence in nature may re-suspend even negatively buoyant materials [47]. Indeed, one important observation in our study is that residual turbulence in our containers after 24 hours of "calm period" was still strong enough to re-suspend nearly $40 \%$ of the dead colonies. Hence, continuous or intermittent turbulence in the sea may be able to keep even negatively buoyant colonies within the surface layer. We therefore expect sinking to be a more important loss factor for Phaeocystis colonies during long quiescent periods.

\section{ACKNOWLEDGEMENTS}

We thank Dr. Walker Smith and Dr. Jörg Dutz for constructive comments and Ms. Xiao Liu for technical assistance. This study was supported by China Scholarship Council Scholarships (XW) and U.S. NSF OCE-0850910 (WOS and KWT). This is contribution no. 3090 of the Virginia Institute of Marine Science.

\section{REFERENCES}

[1] Schoemann V, Becquevort S, Stefels J. Rousseau V, Lancelot C. Phaeocystis blooms in the global ocean and their controlling mechanisms: a review. J Sea Res 2005; 53: 43-66.

[2] Rousseau V, Vaulot D, Casotti R, et al. The life cycle of Phaeocystis (Prymnesiophyceae): evidence and hypotheses. J Mar Syst 1994; 5: 23-39.

[3] Chen YQ, Wang N, Zhang P, Zhou H, Qu LH. Molecular evidence bloom-forming Phaeocystis (Prymnesiophyta) from coastal waters of southeast China as Phaeocystis globosa. Biochem Syst Ecol 2002; 30: 15-22.

[4] van Rijssel M, Hamm CE, Gieskes WWC. Phaeocystis globosa (Prymnesiophyceae) colonies: hollow structures built with small amounts of polysaccharides. Eur J Phycol 1997; 32: 185-192.

[5] Rousseau V, Jacobsen A, Verity P, Whipple S. The life cycle of Phaeocystis: state of knowledge and presumptive role in ecology. Biogeochem 2007; 83: 29-47.

[6] Lancelot C, Billen G, Sournia A, et al. Phaeocystis blooms and nutrient enrichment in the continental zones of the North Sea. AMBIO 1987; 16: 38-46.

[7] Rousseau V, Becquevort S, Parent JY, et al. Trophic efficiency of the planktonic food web in a coastal ecosystem dominated by Phaeocystis colonies. J Sea Res 2000; 43: 357-72.

[8] Smayda TJ. What is a bloom? A commentary. Limnol Oceanogr 1997; 42: 1132-36.

[9] Jacobsen A, Bratbak G, Heldal M. Isolation and characterization of a virus infecting Phaeocystis pouchetii (Prymnesiophyceae). J Phyco 1996; 32: 923-7.
[10] Brussaard CPD, Bratbak G, Baudoux AC, Ruardij P. Phaeocystis and its interaction with viruses. Biogeochem 2007; 83: 201-215.

[11] Lancelot C. The mucilage phenomenon in the continental coastal waters of the North Sea. Sci Total Environ 1995; 165: 83-102.

[12] Tang KW, Smith WO, Shields AR, Elliott DT. Survival and recovery of Phaeocystis antarctica (Prymnesiophyceae) from prolonged darkness and freezing. Proc R Soc B 2009; 276: 81-90.

[13] Jakobsen HH, Tang KW. Effects of protozoan grazing on colony formation in Phaeocystis globosa (Prymnesiophyceae) and the potential costs and benefits. Aquat Microb Ecol 2002; 27: 261-273.

[14] Tang KW. Grazing and colony size development in Phaeocystis globosa (Prymnesiophyceae): the role of a chemical signal. J Plankton Res 2003; 25: 831-842.

[15] Long JD, Smalley GW, Barsby T, Anderson JT, Hay ME. Chemical cues induce consumer-specific defenses in a bloomforming marine phytoplankton. Proc Natl Acad Sci USA 2007; 104:10512-10517.

[16] Hamm CE. Architecture, ecology and biogeochemistry of Phaeocystis colonies. J Sea Res 2000; 43: 307-315.

[17] Nejstgaard J, Tang K, Steinke M, et al. Zooplankton grazing on Phaeocystis: a quantitative review and future challenges. Biogeochem 2007; 83: 147-172.

[18] Skreslet S. Buoyancy in Phaeocystis pouchetii (Hariot) Lagerheim. J Exp Mar Biol Ecol 1988; 119: 157-166.

[19] van Boekel WHM, Hansen WH, Riegman R, Bak RPM. Lysisinduced decline of of phaeocystis spring bloom and coupling with the microbial foodweb. Mar Ecol Prog Ser 1992; 81: 269-276.

[20] Riegman R, van Boekel W. The ecophysiology of Phaeocystis globosa: A review. J Sea Res 1996; 35: 235-242.

[21] Peperzak L, Colijn F, Koeman R, Gieskes WWC, Joordens A Phytoplankton sinking rates in the Rhine region of freshwater influence. J Plankton Res 2003; 25: 365-383.

[22] Becquevort S, Smith WO. Aggregation, sedimentation and biodegradability of phytoplankton- derived material during spring in the Ross Sea, Antarctica. Deep-Sea Res II 2001; 48: 4155-78.

[23] Bienfang PK. SETCOL: A technologically simple and reliable method for measuring phytoplankton sinking rates. Can J Fish Aquat Sci 1981; 38: 1289-94.

[24] Moore JK, Villareal TA. Buoyancy and growth characteristics of three positively buoyant marine diatoms. Mar Ecol Prog Ser 1996; 132: 203-213.

[25] Waite AM, Thompson PA, Harrison, PJ. Does energy control the sinking rates of marine diatoms? Limnol Oceanogr 1992; 37: 468477.

[26] Putt M, Miceli G, Stoecker DK. Association of bacteria with Phaeocystis sp. in McMurdo Sound, Antarctica. Mar Ecol Prog Ser 1994; 105: 179-89.

[27] Guillard RRL, Hargraves PE. Stichochrysis immobilis is a diatom, not a chrysophyte. Phycologia 1993; 32: 234-236.

[28] Peperzak L. Daily irradiance governs growth rate and colony formation of Phaeocystis (Prymnesiophyceae). J Plankton Res 1993; 15: 809-821.

[29] Rousseau V, Mathot S, Lancelot C. Calculation carbon biomass of Phaeocystis sp. from microscopic observations. Mar Biol 1990; 107: 305-314.

[30] Walsby AE, Holland DP. Sinking velocities of phytoplankton measured on a stable density gradient by laser scanning. J Roy Soc Interface 2006; 3: 429-439.

[31] Eppley RW, Holmes W, Paasche E. Periodicity in cell division and physiological behaviour of Ditylum brightwellii, a marine planktonic diatom, during in light-dark cycles. Arch Microbiol 1967; 56: 305-323

[32] Anderson LWJ, Sweeney BM. Diel changes in sedimentation characteristics of Ditylum brightwelli: changes in cellular lipid and effects of respiratory inhibitors and ion-transport modifiers. Limnol Oceanogr 1977; 22: 539-52.

[33] van Rijn J, Shilo M. Carbohydrate fluctuations, gas vacuolation, and vertical migration of scum-forming cyanobacteria in fishponds. Limnol Oceanogr 1985; 30: 1219-28.

[34] Romans KM, Carpenter EJ, Bergman B. Buoyancy regulation in the colonial diazotrophic cyanobacterium Trichdesmium tenue: ultrastructure and storage of carbohydrate, olyphosphate, and nitrogen. J Phycol 1994; 30: 935-42.

[35] Visser PM, Ibelings BW, Mur LR. Autumnal sedimentation of Microcystis spp. as a result of an increase in carbohydrate ballast at reduced temperature. J Plankton Res 1995; 17: 919-33. 
[36] Alderkamp AC, Nejstgaard JC, Verity PG, Zirbel MJ, Sazhin AF, van Rijssel $M$. Dynamics in carbohydrate composition of Phaeocystis pouchetii colonies during spring blooms in mesocosms. J Sea Res 2006; 55: 169-181.

[37] Smayda TJ. The suspension and sinking of phytoplankton in the sea. Oceanogr Mar Biol Annu Rev 1970; 8: 353-414.

[38] Sukenik A, Carmeli Y. Lipid synthesis and fatty acid composition Nannochloropsis sp. (Eustigmatophyceae) growth in a light-dark cycle. J Phycol 1990; 26: 463-469.

[39] Verity PG, Villareal TA, Smayda TJ. Ecological investigations of blooms of colonial Phaeocystis pouchetti. 1. Abundance, biochemical composition, and metabolic rates. J Plankton Res 1988; 10: 219-248.

[40] Veldhuis MJW, ColijnF, Admiraal W. Phosphate utilization in Phaeocystis pouchetii (Haptophyceae). Mar Ecol 1991; 12: 53-62.

[41] Lancelot C, Mathot S. Biochemical fractionation of primary production by phytoplankton in Belgian coastal waters during short- and long-term incubations with ${ }^{14} \mathrm{C}$-bicarbonate. Mar Biol 1985; 86: 219-226.
[42] Riebesell U, Reigstad M, Wassmann P, Noji T, Passow U. On the trophic fate of Phaeocystis pouchetii (Hariot): VI. Significance of Phaeocystis-derived mucus for vertical flux. Neth J Sea Res 1995; 33: 193-203.

[43] Ploug H, Stolte W, Jørgensen BB. Diffusive boundary layers of the colony-forming plankton alga Phaeocystis sp.-implications for nutrient uptake and cellular growth. Limnol Oceanogr 1999; 44: 1959-67.

[44] Smetacek VS. Role of sinking in diatom life-history cycles: ecological, evolutionary and geological significance. Mar Biol 1985; 84: 239-251.

[45] Wassmann P, Vernet M, Mitchell G, Rey F. Mass sedimentation of Phaeocystis pouchetii in the Barents Sea during spring. Mar Ecol Prog Ser 1990; 66: 183-195.

[46] Reigstad M, Wassmann P. Does Phaeocystis spp. contribute significantly to vertical export of organic carbon? Biogeochem 2007; 83: 217-234

[47] Jenness MI, Duineveld GCA. Effects of tidal currents on chlorophyll $a$ content sandy sediments in the southern North Sea. Mar Ecol Prog Ser 1985; 21: 283-287.

Received: April 11,2010

(C) Wang and Tang; Licensee Bentham Open.

This is an open access article licensed under the terms of the Creative Commons Attribution Non-Commercial License (http://creativecommons.org/licenses/by$\mathrm{nc} / 3.0 /$ ), which permits unrestricted, non-commercial use, distribution and reproduction in any medium, provided the work is properly cited. 